\title{
Plasma Treatment Limits Cutaneous Squamous Cell Carcinoma Development In Vitro and In Vivo
}

\author{
Gabriella Pasqual-Melo ${ }^{1}$, Thiago Nascimento ${ }^{2}$, Larissa Juliani Sanches ${ }^{2}$, \\ Fernanda Paschoal Blegniski ${ }^{2}$, Julya Karen Bianchi ${ }^{2}$, Sanjeev Kumar Sagwal ${ }^{1}$, Julia Berner ${ }^{1,3}$, \\ Anke Schmidt ${ }^{1}{ }^{\circledR}$, Steffen Emmert ${ }^{4}$, Klaus-Dieter Weltmann ${ }^{1}$, Thomas von Woedtke ${ }^{1,5}{ }^{\circledR}$, \\ Rajesh Kumar Gandhirajan ${ }^{1,+}$, Alessandra Lourenço Cecchini ${ }^{2,+}$ and Sander Bekeschus ${ }^{1, *}$ (i) \\ 1 ZIK plasmatis, Leibniz Institute for Plasma Science and Technology (INP), Felix-Hausdorff-Str. 2, \\ 17489 Greifswald, Germany; gabriella.pasqual-melo@inp-greifswald.de (G.P.-M.); \\ sanjeev.sagwal@inp-greifswald.de (S.K.S.); julia.berner@inp-greifswald.de (J.B.); \\ anke.schmidt@inp-greifswald.de (A.S.); weltmann@inp-greifswald.de (K.-D.W.); \\ woedtke@inp-greifswald.de (T.v.W.); rajesh.gandhirajan@inp-greifswald.de (R.K.J.) \\ 2 Department of General Pathology, State University of Londrina, Rodovia Celso Garcia Cid, \\ Londrina 86051-990, Brazil; thiagohenrique_d_n@hotmail.com (T.N.); larisanches_89@hotmail.com (L.J.S.); \\ fpblegniski@gmail.com (F.P.B.); julya.bianchi@gmail.com (J.K.B.); alcecchini@uel.br (A.L.C.) \\ 3 Clinic for Oral, Maxillofacial, and Plastic Surgery, Greifswald University Medical Center, Sauerbruchstr., \\ 17475 Greifswald, Germany \\ 4 Clinic for Dermatology and Venereology, Rostock University Medical Center, Strempelstr. 13, \\ 18057 Rostock, Germany; steffen.Emmert@med.uni-rostock.de \\ 5 Institute for Hygiene and Environmental Medicine, Greifswald University Medical Center, \\ Walther-Rathenau-Str. 48, 17489 Greifswald, Germany \\ * Correspondence: sander.bekeschus@inp-greifswald.de; Tel.: +49-3834-554-3948 \\ + Authors contributed equally to this work.
}

Received: 2 June 2020; Accepted: 17 July 2020; Published: 21 July 2020 updates

\begin{abstract}
Cutaneous squamous cell carcinoma (SCC) is the most prevalent cancer worldwide, increasing the cost of healthcare services and with a high rate of morbidity. Its etiology is linked to chronic ultraviolet (UV) exposure that leads to malignant transformation of keratinocytes. Invasive growth and metastasis are severe consequences of this process. Therapy-resistant and highly aggressive SCC is frequently fatal, exemplifying the need for novel treatment strategies. Cold physical plasma is a partially ionized gas, expelling therapeutic doses of reactive oxygen and nitrogen species that were investigated for their anticancer capacity against SCC in vitro and SCC-like lesions in vivo. Using the kINPen argon plasma jet, a selective growth-reducing action of plasma treatment was identified in two SCC cell lines in 2D and 3D cultures. In vivo, plasma treatment limited the progression of UVB-induced SSC-like skin lesions and dermal degeneration without compromising lesional or non-lesional skin. In lesional tissue, this was associated with a decrease in cell proliferation and the antioxidant transcription factor Nrf2 following plasma treatment, while catalase expression was increased. Analysis of skin adjacent to the lesions and determination of global antioxidant parameters confirmed the local but not systemic action of the plasma anticancer therapy in vivo.
\end{abstract}

Keywords: kINPen; plasma medicine; plasma sources; reactive oxygen and nitrogen species; cutaneous squamous cell carcinoma (SCC)

\section{Introduction}

Non-melanocytic skin cancer (NMSC) is one of the most frequently diagnosed types of cancer [1]. It includes, for instance, basal cell carcinoma (BCC) and squamous cell carcinoma (SCC), which represent 
up to $20 \%$ of all skin cancers [2]. Recent work using genetic mouse models of BCC described that stem and progenitor cells are the probable sources of BCC initiation [3]. This type of NMSC can be locally destructive, but metastasis is rare [4]. SCC is more aggressive and characterized by an uncontrolled proliferation of squamous cells in the epidermal layer. Invasive SCC shows masses of atypical keratinocytes proliferating into the dermis. SCCs often contain squamous pearls, a keratinized structure, wherein abnormal squamous cells form concentric layers and occasionally mitotic figures [5]. Frequent exposure to ultraviolet (UV) light is described as an inducer of NMSCs. Especially, UVB exposure is known to be the principal carcinogenic agent that causes mutations in the DNA of keratinocytes, leading to the development of SCC [5], the so-called multistep photocarcinogenesis. For the SCC, intermittent sun exposure in the early decades is also part of its etiology [6]. A more detailed view of SCC etiology, pathogenesis, and treatment options has been outlined previously [7-9]. Here, we tested a UVB irradiation protocol, which led the development of SCC in nude mice.

Cold physical plasma is a highly energetic, partially ionized gas that can be operated at body temperatures [10]. One of the major biologically active components of medically relevant cold physical plasma devices is reactive oxygen and nitrogen species (ROS/RNS) formed through reactions with molecules present in the ambient air. The range of applications for this technology mainly includes dermatology and skin-based infections, oncology, and dentistry, among others [11-13]. Plasma treatment of non-healing wounds and ulcers is the most established clinical application to date, as evidenced by several approved medical plasma devices in Europe [14]. Oncology is an emerging topic in plasma medicine, with positive results achieved so far in preclinical research on skin cancer [15-17]. Several palliative tumor patients have already benefited from plasma therapy [18,19]. In contrast to chemotherapy and radiotherapy, a feature of medical plasma applications is the lack of side effects observed so far in the preclinical [20-22] and clinical setting [23-25]. Another attractive feature of plasma treatment is a certain degree of selectivity for killing cancer cells, predominantly via apoptosis [26-29]. More detailed views on plasmas for cancer treatment have been reviewed recently [30-32].

Several promising targeted agents for SCC treatment exist, including epithelial growth factor receptor (EGFR) antagonists, small-molecule tyrosine kinase inhibitors (TKIs), proteasome inhibitors, and anti-PD-1/PD-L1 antibodies [5]. However, these therapies come at high costs and often with severe side-effects, motivating the development of novel antitumor approaches and technologies targeting SCC or preventing its progression from lesions. In the present study, we tested cold physical plasma as an in-this-field novel agent for tackling skin squamous cell carcinoma in vitro and its development and progression in vivo.

\section{Results}

\subsection{Plasma Treatment Was Selectively Cytotoxic to SCC Cells In Vitro}

To analyze the cytotoxicity of plasma treatment in 2D cultured cells in vitro, the metabolic activity of SCC cells (A431, SSC13) and HaCaT keratinocytes were analyzed $24 \mathrm{~h}$ after plasma exposure (Figure 1A). A treatment time-dependent decline was observed, and plasma treatment was significantly more cytotoxic in malignant keratinocytes (A431, SCC13) compared to non-malignant keratinocytes (HaCaT). Next, the cytotoxicity of plasma was investigated in 3D multicellular spheroids using high content imaging microscopy (Figure 1B). HaCaT keratinocytes do not form 3D spheroids, which is why they could not be studied using this assay. Plasma treatment showed a treatment time-dependent cytotoxicity in SCC13 (Figure 1C) and A431 (Figure 1D) cells. 
A

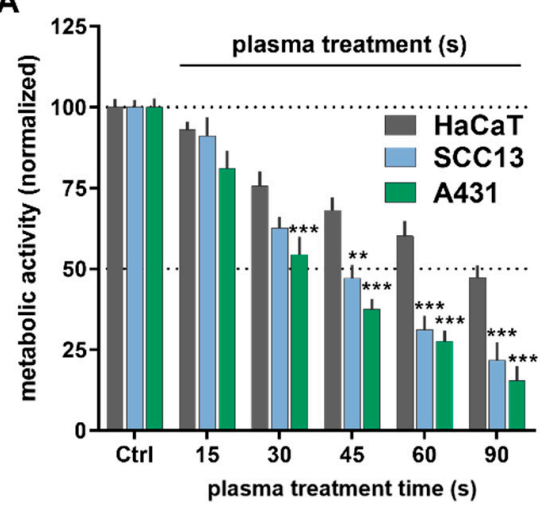

B
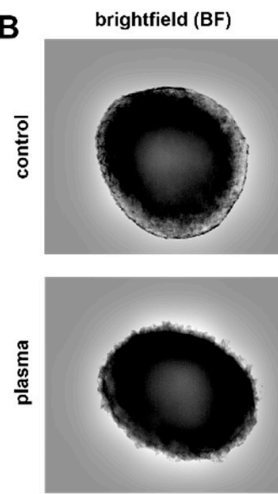

sytox blue (SB)
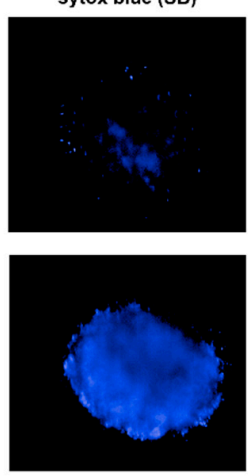

$\mathrm{BF}+\mathrm{SB}$
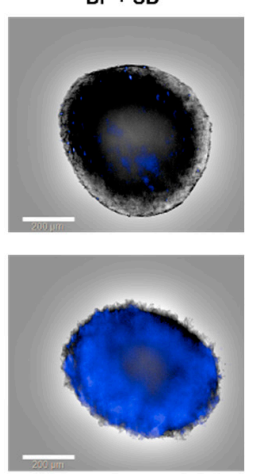

C

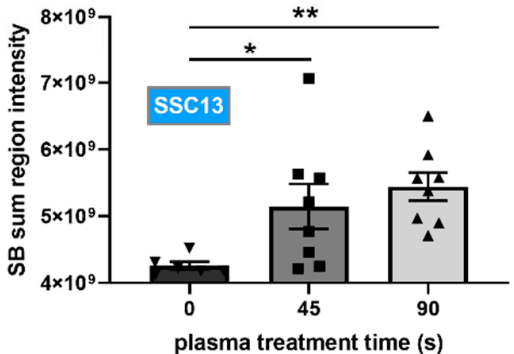

D

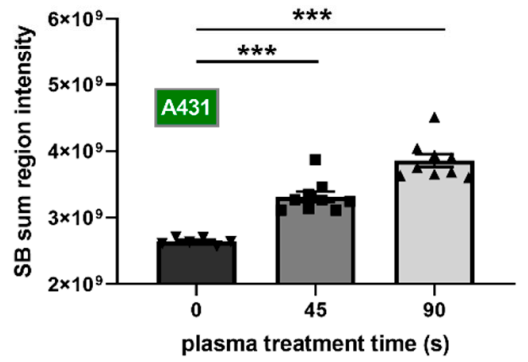

Figure 1. Plasma treatment of SCC in vitro. (A) Metabolic activity of malignant squamous cell carcinoma (SCC) (A431, SCC13) and non-malignant HaCaT keratinocytes $24 \mathrm{~h}$ post-exposure to plasma; (B) representative images of 3D tumor spheroids with and without plasma treatment (90s); (C,D) quantitative sytox blue (SB) analysis in SCC13 (C) and A431 (D) tumor spheroids $24 \mathrm{~h}$ post plasma treatment. Results are expressed as the mean \pm SEM, from 2 to 3 experiments with several replicates each. Statistical analysis was performed using two-way, (A) against HaCaT keratinocytes, or one-way (C,D) analysis of variances against the control condition with $p<0.05\left(^{*}\right), p<0.01\left({ }^{* *}\right)$, and $\left.p<0.001{ }^{* * *}\right)$. Scale bar $=200 \mu \mathrm{m}$.

\subsection{Growth of UVB-Induced Skin Lesions Was Limited by Plasma Treatment}

The next question was whether plasma treatment also showed efficacy against the progression of UVB-induced skin lesions in vivo. For this, a syngeneic model in nude, immunocompetent mice was used. UVB light was used to induce skin lesions with features of cutaneous SCCs in these animals. After 7 weeks of UVB radiation, according to our protocol (Figure 2A), the animals developed skin lesions comparable with histopathological characteristics of SCC (Figure 2B). In the following weeks, the skin lesions were subjected to plasma treatment in alternated days with continued UVB irradiation to see whether plasma treatment alters the development of the disease (Figure 2C). After 4 weeks of plasma treatment, the animals were euthanized and the skin lesions and their progression status were analyzed via histopathology, according to standardized parameters, as previously described [33]. Unlike the control groups (Figure 3A,B), the UVB irradiation induced an increase of epidermal thickness (Figure 3C,E). Plasma treatment controlled this growth (Figure 3D,E). Blinded histopathological scoring was used to evaluate several characteristics of putative carcinogenic transformation. It was found that plasma treatment significantly reduced the degree of follicular atrophy, dermal degeneration, and keratin pearls induced by the UVB treatment (Figure 3F). At the same time, repeated plasma treatment of the skin of mice not subjected to UVB treatment did not induce pathological or pre-malignant alterations of the skin, as evidenced by the lack of epidermal thickening, follicular atrophy, dermal degeneration, and keratin pearls (Figure 3E,F). These results suggested that plasma treatment was not only safe to be applied onto the skin but also was able to control the growth and consequences of malignant keratinocytes growth in vivo. 
A

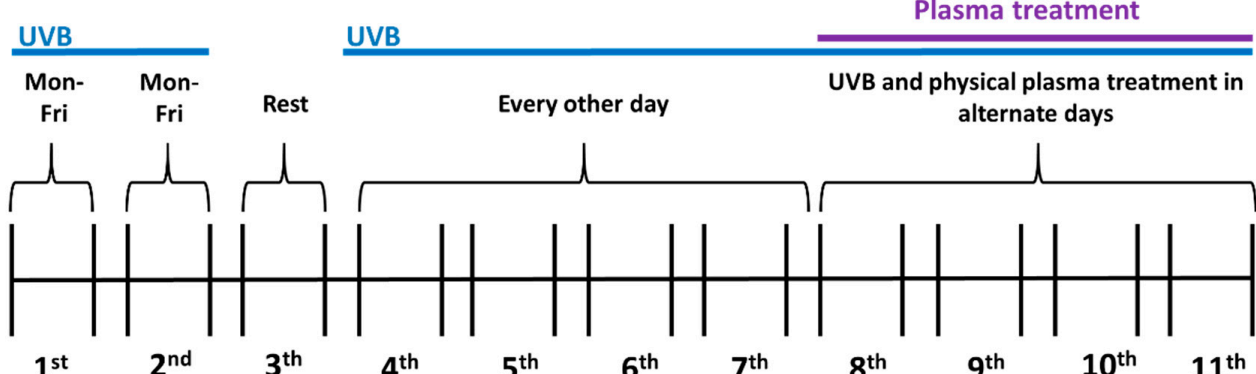

$1^{\text {st }}$

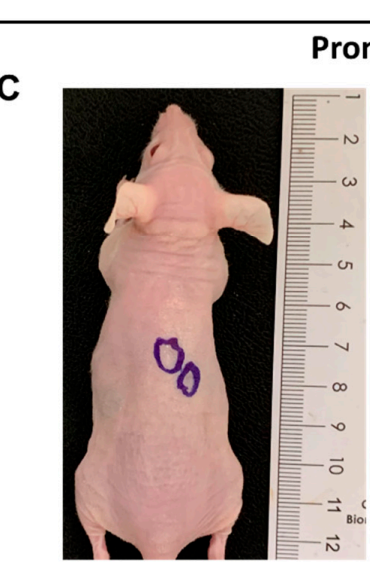

\section{Initiation phase}

B

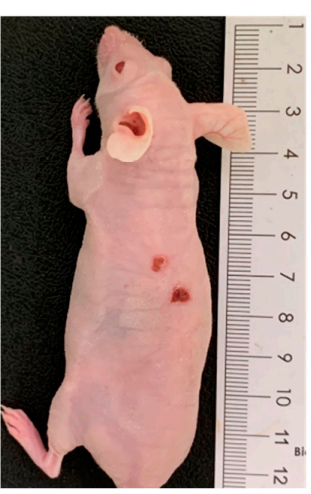

Promotion phase

Figure 2. Animal model of UVB-induced skin lesions. (A) Timeline of the experiment; (B) representative animal of the UVB group right before the first plasma treatment (at the end of the seventh week); (C) representative animal of the plasma treatment group (without UVB-induced lesions, at the end of the 11th week after several plasma treatments); the circles indicate the location of the plasma treatment.

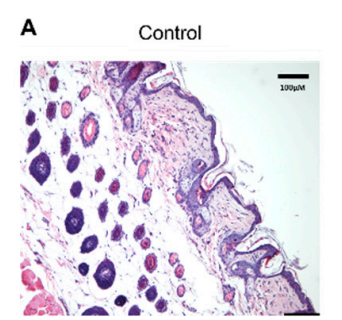

E

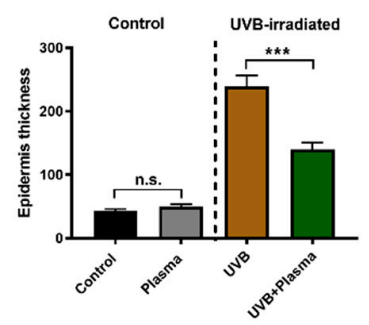

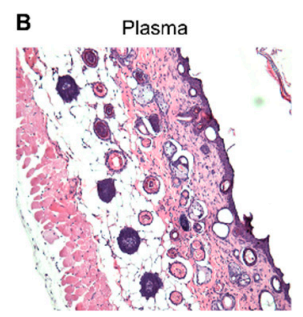

$\mathbf{F}$

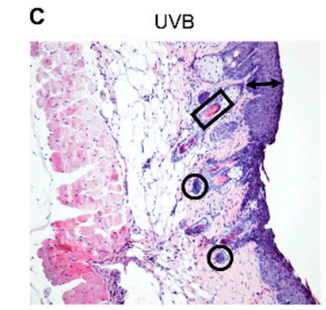

Folicular atrophy

Dermal degeneration

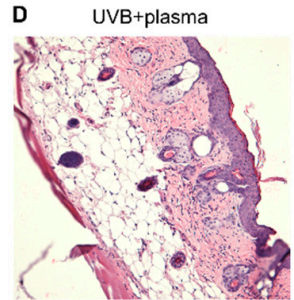

Keratin pearls
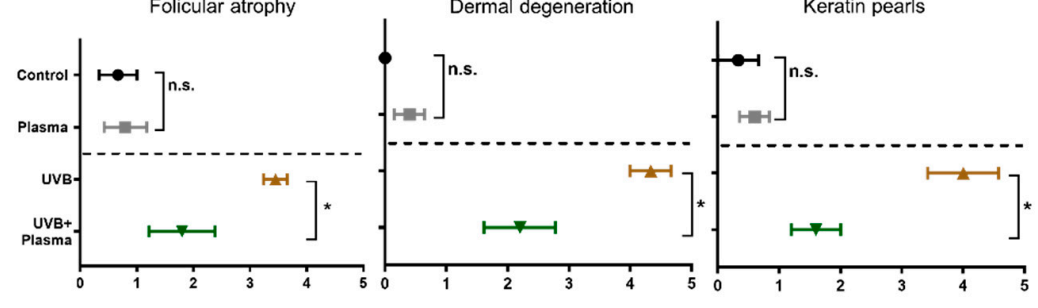

Histophatological Score

Figure 3. Histopathological evaluation. (A-D) Representative images of murine skin sections stained with hematoxylin and eosin (H\&E) from the untreated (control) (A), plasma (B), UVB (C), and UVB + plasma (D) treated mice, respectively $(40 \times)$; (E) quantification of the epidermal thickness (see black arrow in C as an example); (F) histopathological score of characteristics related to SCC, which includes follicular atrophy, dermal degeneration, and keratin pearls (see black square in C as an example) [33]. The black circles (C) indicate nests of dysplastic squamous cells reaching the dermis. Results are expressed as the mean \pm SEM from 4 to 5 animals per group. Statistical analysis was performed using an unpaired t-test with $p<0.05\left(^{*}\right)$ and $p<0.001\left(^{* * *}\right)$. Scale bar $=100 \mu \mathrm{m} ;$ n.s. $=$ not significant. 


\subsection{Plasma Treatment Decreased Proliferation in UVB-Induced Skin Lesions}

To analyze putative mechanisms related to the effects observed, immunohistochemical analysis of the UVB-induced skin lesions was performed. Since plasma treatment generates a plethora of reactive oxygen and nitrogen species simultaneously, which subsequently act on the skin, it was natural to investigate parameters of the antioxidant defense. Plasma treatment induced an increase of catalase in both non-UVB-treated skin and UVB-treated skin (Figure 4A-D and Q). This demonstrated that plasma treatment was recognized as a therapeutic agent in skin cells, leading to an increased translation of the antioxidant enzyme catalase. Catalase expression is under the control of nuclear factor E2-related factor 2 (Nrf2) [34], an essential antioxidant transcription factor. Accordingly, the tissues were stained for Nrf2 expression (Figure 4E-H and R), and its significant upregulation in UVB-challenged skin of mice was found (Figure 4G). In contrast, plasma treatment significantly reduced Nrf2 levels in UVB-induced skin lesions (Figure $4 \mathrm{H}$ ), suggesting alternative pathways increasing catalase expression in this condition. However, Nrf2 levels were markedly elevated in UVB-treated skin compared to non-irradiated skin, indicating a putative involvement of Nrf2 in the pathology of SCC. Since plasma generates a wealth of free radicals that were previously linked to genotoxic activity, the next question was whether plasma treatment increased the presence of oxidative DNA products as assayed using 8-hydroxy-2' - deoxyguanosine (8-OHdG) antibodies. As expected, the UVB-induced SSC lesions showed a substantial elevation of $8-\mathrm{OHdG}$ staining when compared to unirradiated skin (Figure I-L and S). Plasma treatment was observed to elevate the levels of 8-OHdG significantly; however, it was not observed in non-UVB-irradiated skin (Figure 4I,J) or UVB-induced skin lesions (Figure 4K,L). This supports previous reports that a direct genotoxic effect of plasma-derived reactive species in living cells is unlikely $[20,21,35]$. Finally, tissue staining of the cell proliferation marker Ki67 was performed (Figure 4M-P and T). Interestingly, plasma treatment of non-irradiated, healthy skin significantly promoted the proliferation of cells in this tissue (Figure $4 \mathrm{M}, \mathrm{N}$ ). This is in line with the wound-healing promoting properties reported for the kINPen plasma therapy [36]. By contrast, plasma treatment of UVB-induced skin lesions significantly decreased the pathological proliferation of this cancerous condition (Figure 4O,P). Altogether, our data confirm not only the stimulating properties of plasma therapy in healthy skin but also the growth-controlling effects of plasma treatment in malignant skin disease. 


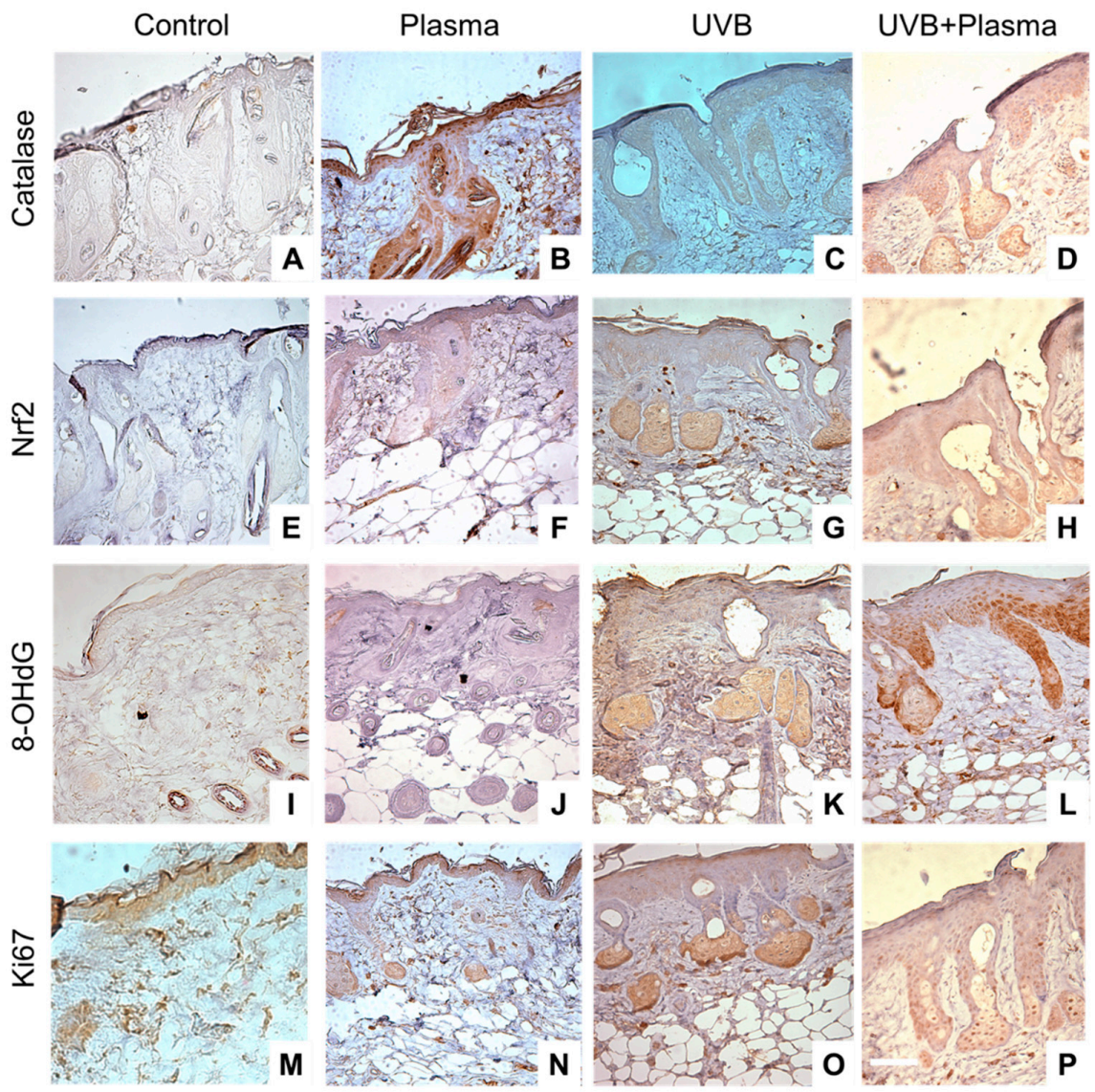

Q

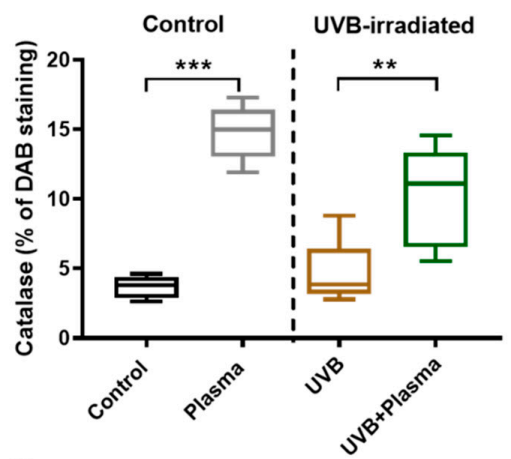

S

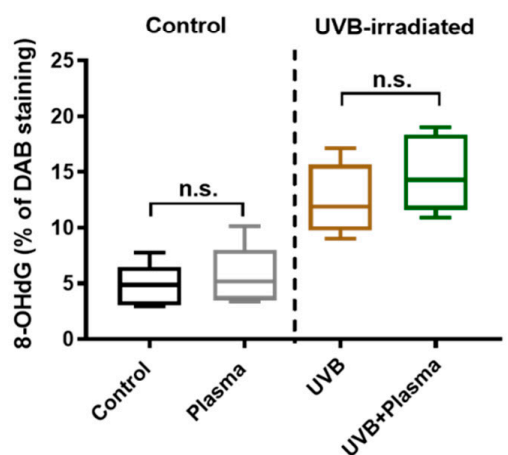

R

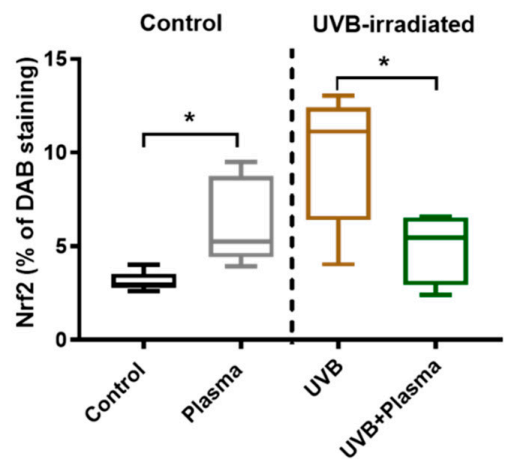

T

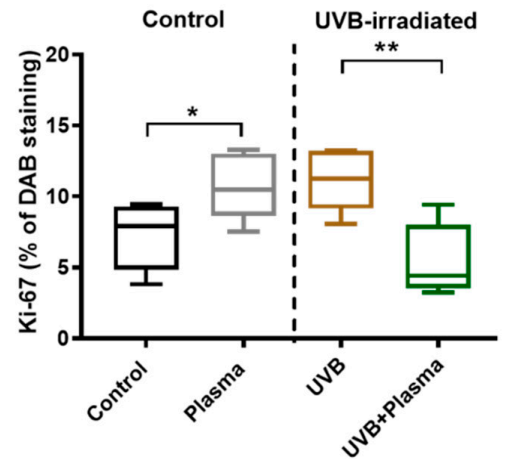

Figure 4. Immunohistochemistry. (A-P) Representative tissue sections stained with antibodies targeting 
catalase (A-D), nuclear factor E2-related factor 2 (Nrf2) (E-H), 8-hydroxy-2' — deoxyguanosine (8-OHdG) (I-L), and Ki-67 (M-P) in control, plasma, UVB, and UVB + plasma treated mice $(100 \times) ;(\mathbf{Q}-\mathbf{T})$ quantification of 3,3'-diaminobenzidine (DAB) staining. Results are expressed as boxplots from 4 to 5 animals per group. Statistical analysis was performed using an unpaired t-test with $p<0.05\left(^{*}\right)$, $p<0.01{ }^{(* *)}$, and $p<0.001\left(^{* * *}\right)$. Scale bar $=200 \mu \mathrm{m} ;$ n.s. $=$ not significant.

\subsection{Analysis of Remote Skin and Systemic Antioxidants Confirmed the Local Activity of Plasma}

It is known, and further evidence was provided in this work, that plasma treatment has profound effects, seen locally at the site of treatment [24,37-40]. It is often assumed that such effects do not spread regionally or systemically, but direct evidence of this assumption is scarce. Skin that was adjacent (several millimeters apart) to the plasma treatment sites was therefore investigated for several antioxidant parameters. This was done in both mice with UVB-induced skin lesions and non-irradiated mice. Analysis of the major antioxidant glutathione (GSH, Figure 5A), as well as the total antioxidant capacity as determined by total radical trapping antioxidant parameter (TRAP) assay (Figure 5B), did not show any significant difference between animals subjected to plasma treatment and non-irradiated controls. However, when analyzing the amount of active catalase, a small but significant decrease was observed in the UVB group (Figure 5C). Next, a potentially systemic action of plasma treatment was investigated by analyzing erythrocytes. The amount of GSH (Figure 5D), superoxide dismutase (SOD) activity (Figure 5E), and lipid peroxidation (malondialdehyde (MDA), Figure 5F) in blood plasma was not significantly different between the plasma-treated and non plasma-treated animals. This indicates that the activity of plasma-derived reactive species is mainly limited to the treatment site, potentially with small regional but not systemic effects of the exposure.

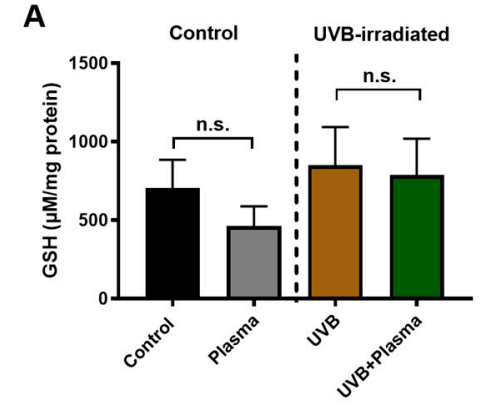

D

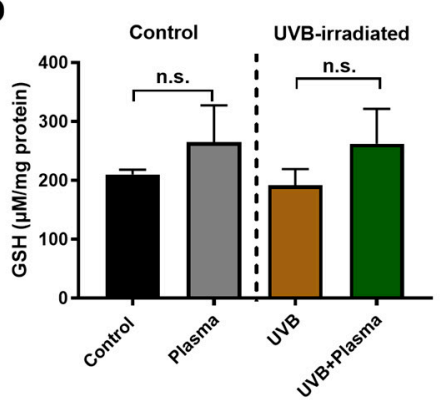

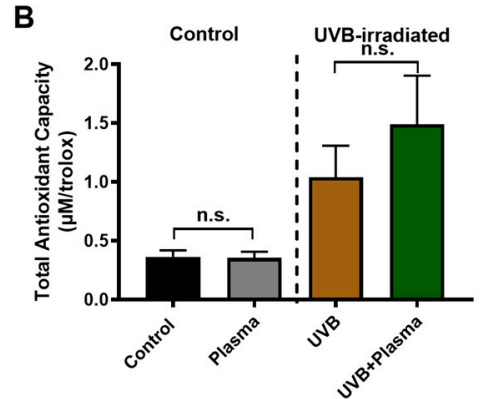

E

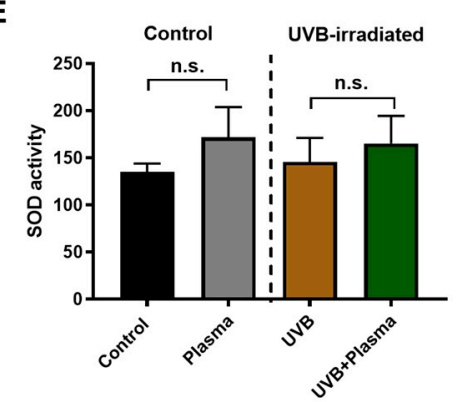

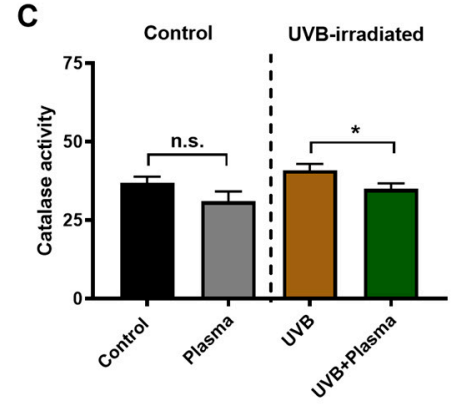

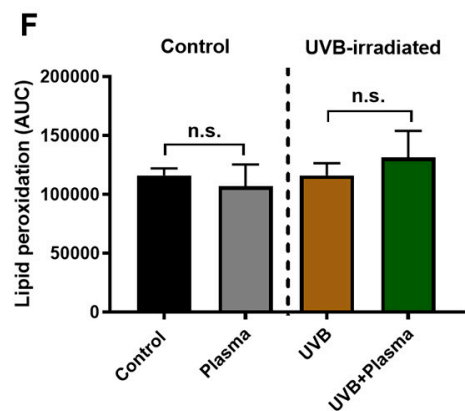

Figure 5. Systemic antioxidants and analysis of non-lesional, adjacent skin. (A-C) Analysis of adjacent skin for GSH content (A), total-trapping antioxidant capacity (B), and catalase activity (C); (C-F) analysis of systemic antioxidants in red cells of GSH (D), superoxide dismutase (SOD) (E), and lipid peroxidation (F). Results are expressed as boxplots from 3 to 5 animals per group. Statistical analysis was performed using an unpaired t-test with $p<0.05(*)$; n.s. = not significant.

\section{Discussion}

SCC is characterized by an atypical proliferation of invasive squamous cells under extensive progression [41]. Although the vast majority of SCC can be treated with local or surgical destructive 
methods, a more aggressive subgroup can metastasize and induce significant morbidity and mortality [42]. Furthermore, large recurrent tumors, deeper than $2 \mathrm{~mm}$, undifferentiated cells, and invading perineural or lymphovascular structures are some characteristics of a more aggressive SCC [43]. Several risk factors have been described for the development of SCC, but exposure to UVB irradiation for many decades that stands out as the most harmful [44]. Among the UV spectrum, UVB has higher energy levels than UVA and typically damages the outermost layers of the skin, interacting directly and indirectly with DNA [45], eventually causing skin cancer [33]. Our study showed that the animals developed a macroscopic skin lesion with histopathological characteristics similar to those of SCC after 7 weeks of UVB-irradiation. Plasma treatment was used as a therapeutic intervention, which limited cell proliferation in the lesions.

For SCC, surgery is the treatment of choice, and radiotherapy is performed when the cancer is inoperable. However, both lead to ablation, not only of the tumor but of a large perimeter of the skin, not to mention the side effects caused by radiotherapy [46]. A therapeutic alternative that doesn't not lead to mutilations and deformities is required. Several reports have noted a decline in SCC growth after plasma treatment. In a xenograft model in immunodeficient mice, human SCC cells were injected subcutaneously and treated with plasma daily [47]. Besides a reduction of tumor growth, an increase in caspase-3 and apoptosis, as well as NADPH-oxidase 3 (NOX3), was observed in the plasma-treated tumor tissue. NOX3 activity is restrained by toll-like-receptor 4 (TLR4) signaling [48], and a higher expression or activation of NOX3 results in enhanced superoxide production, which rapidly dismutates to hydrogen peroxide $\left(\mathrm{H}_{2} \mathrm{O}_{2}\right)$ [49]. Although NOX3 expression was not investigated in the present work, it is possible that increased endogenous ROS production may have contributed to increasing catalase expression observed in our model, an enzyme that scavenges $\mathrm{H}_{2} \mathrm{O}_{2}$ [50]. A study that subcutaneously injected syngeneic murine SCC7 cells into $\mathrm{C} 3 \mathrm{H} / \mathrm{HeJ}$ mice showed a reduction of tumor growth after daily treatment with plasma for 1 week [51]. The authors found an increase in mitochondrial E3 ubiquitin-protein ligase 1 (MUL1) levels, a protein responsible for the degradation of, e.g., the pro-oncogenic kinase, AKT (protein kinase B). The results were confirmed in a xenograft SCC animal model in the same study, giving evidence that plasma treatment is capable of reducing cell growth of injected SCC cells in vivo. However, we show here for the first time that plasma treatment also limits endogenously generated, UVB-induced skin lesions with characteristics of SCC. As our model is per definitionem syngeneic, it is conceivable in this regard that cells of the immune system also might have contributed to the effects observed, as some reports in the literature have suggested plasma cancer treatment for skin cancer-bearing mice $[15,16,52,53]$.

In our study, the effects of plasma treatment on healthy skin not subjected to UVB radiation and subsequent induction of pathological skin characteristics was tested. Plasma treatment did not induce increased epidermal thickening, follicular atrophy, dermal degeneration, or keratin pearls, all being a hallmark of SCC in this mouse model and appearing with constant UVB irradiation [54]. This absence of tumorigenic potential was also previously shown in our work using SKH1 mice and investigation of tissues 1 year after repetitive plasma treatment [21]. Similar findings were made in volunteers with plasma-treated, laser-induced wounds in a 1-year follow up study [24]. Moreover, a significant increase in oxidative DNA products was not found, which would be representative of excessive plasma-induced DNA damage being potentially mutagenic. For this, 8-hydroxy-2' —-deoxyguanosine (8-OHdG) was quantified, being one of the predominant forms of ROS-induced oxidative DNA alteration [55]. Although several reports have speculated DNA-damaging properties of plasma treatment [56-60], these reports usually did not use gold-standard assays of genotoxic research or only partially adhered to them to confirm their results. Our previous reports did not find, for instance, an increase in micronucleus formation following plasma treatment $[20,35,61]$, being a gold standard assay, according to the OECD (Organisation for Economic Co-operation and Development) for toxicity research. A lack of genotoxicity was also obtained using the HPRT (Hypoxanthin-Guanin-Phosphoribosyltransferase) test [22], another OECD accredited assay. Analyzing the sub-G1 fraction during cell cycle analysis, as done by some studies, is not an indicator of DNA damage but a regular event during the apoptotic cascade, where 
DNA is cleaved into smaller pieces to avoid excessive inflammation. Hence, the appearance of sub-G1 cells in the cell cycle analysis takes place for any toxic stimulus, regardless of its DNA-damaging nature. Additionally, many reports use the presence of phosphorylated histone $2 \mathrm{AX}(\gamma \mathrm{H} 2 \mathrm{AX})$ as a marker for DNA double-strand breaks. While this seems intuitive, since $\gamma \mathrm{H} 2 \mathrm{AX}$ is a frequently used marker in radiobiology [62], we recently discovered that following plasma treatment with $\gamma \mathrm{H} 2 \mathrm{AX}$ is a consequence of apoptosis rather than its cause due to genotoxic events [35]. Therefore, and in line with previous reports in vitro, in vivo, and in patients, plasma treatment indisputably seems to be safe in our model in terms of pathological transformation in vivo. Moreover, this work mounts direct evidence that the action of plasma treatment is mainly localized to the site of treatment and does not affect the systemic redox status.

Our results confirmed the stimulating properties of plasma treatment in the skin that possibly contribute to the promotion of wound healing. This links to previous results with the kINPen treatment of wounds where, similar to our findings, an increase in cell proliferation and expression of Nrf2 and catalase was observed [36]. An increase in cell proliferation following plasma treatment was also previously observed in vitro in human HaCaT keratinocytes $[63,64]$. Ex vivo human skin exposed to plasma confirmed such an increase of proliferation in keratinocytes, while an increase of $\gamma \mathrm{H} 2 \mathrm{AX}$ was not found [65]. Such a dual role of plasma treatment being stimulating or toxic, depending on the state of the cells or tissues being targeted, was previously noted already [26,28]. Nrf2 is a potential biomarker of head and neck SCC and its expression correlates with disease appearance [66]. Plasma treatment reduced Nrf2 levels in our murine model of UVB-induced skin lesions, suggesting the involvement of Nrf2 in SCC pathogenesis [67]. In general, it is noteworthy that, in our study, plasma treatment increased Nrf2 levels in normal skin while reducing Nrf2 levels in UVB-induced skin lesions. It is a regularly observed phenomenon in biology that a silent pathway is prone to activation induced by an agent, while an overactive pathway receiving additional stimuli experiences negative feedback regulation, ultimately resulting in its downregulation, as seen, for example, for nitric oxide in macrophages [68]. For Nrf2, negative feedback regulation is also described through interaction with KEAP1 (Kelch-like ECH-associated protein 1) and ATF3 (Activating Transcription Factor 3) [69], as well as GSK-3 $\beta$ (Glycogen Synthase Kinase 3 Beta) [70], mechanisms possibly triggered by plasma treatment.

The selective toxicity of plasma treatment in vitro was demonstrated since human malignant keratinocytes (SCC) were significantly more sensitive to plasma treatment compared to human non-malignant (HaCaT) keratinocytes. This is in line with previous reports, showing a cytotoxic action and self-amplification of mitochondrial ROS production, following treatment in various human SCC cell lines, including FaDu, SNU1041, OSC19, SNU800, and HN9 [47,71,72]. Another study reported the involvement of catalytic iron in eliciting ferroptosis in plasma-treated human and mouse SCC lines, such as SAS, Ca9-22, HSC-2, HSC-3, HSC-4, Sa3, and Ho-1-u-1 [73]. This and another work [29] also suggested a certain degree of selectivity of plasma treatment towards cancer cells. This might be based on differences in the signaling responses translating a pro-oxidant milieu into cell death. For plasma medicine, molecules involved in this process might be related to, for instance, the Nrf2 pathway [36,74,75], heme oxygenase 1 (HMOX1) [76], or other antioxidant response elements [77]. Others have suggested that the lipid composition of tumor cells [78-80] and the expression of aquaporins [81-83] are also important for the selectivity of plasmas towards malignant cells. Plasma generates different ROS, such as ozone $\left(\mathrm{O}_{3}\right)$, superoxide $\left(\mathrm{O}_{2}{ }^{-}\right)$, singlet delta oxygen $\left({ }^{1} \mathrm{O}_{2}\right)$, atomic oxygen $(\mathrm{O})$, hydroxyl radical $\left({ }^{\bullet} \mathrm{OH}\right)$, and hydrogen peroxide $\left(\mathrm{H}_{2} \mathrm{O}_{2}\right)$ [84-93]. A study comparing different plasma feed gas compositions suggested thar nitrogen plasma inhibits SCC growth and migration most potently [94], which is in line with another report, which found nitric oxide (NO) to be important [95]. The kINPen plasma jet used in our study generates both reactive nitrogen species and NO, among other species [96]. This jet also generates a number of other types of reactive species, as thoroughly outlined in a recent review [97]. Which of these species are predominant in mediating effects in vivo is currently a topic of investigation, and conclusions are limited by the types of analysis available in distinguishing several types of reactive species from each other. For the 
in vitro results, the dominant types of ROS mediating an effect are long-lived oxidants, such as $\mathrm{H}_{2} \mathrm{O}_{2}$, and possibly nitrite and nitrate $[98,99]$. However, in vivo, other plasma agents may have contributed to the effects observed. The kINPen generates UV radiation but only to a low amount (1/30 of the allowed radiation) [100], at least in the non-conductive mode. Moreover, the UV treatment, but not the plasma treatment, led to SCC lesions in our animal model, exemplifying that the biologically relevant UV emission of the kINPen is not pathological. Our plasma jet also generates thermal radiation, but this is in the range of body temperature, making a contribution of heat to the effects of plasma observed unlikely. Another attribute of plasma is the presence of electric fields. However, argon plasma jets, such as the kINPen, have significantly lower electric field intensities compared to helium plasma jets or dielectric barrier discharges. This is exemplified by the fact that the electric field of the kINPen is insufficient to induce immediate permeabilization of the cell membrane [101]. The possibility of electrons and ions generated by the plasma contributing to the effects observed in vivo cannot be excluded.

An underexplored research avenue is the combination of plasma treatment with existing therapeutic regimens to potentiate cytotoxic effects against SCC. Already in 2009, a proof-of-concept study suggested additive cytotoxicity of antibody-conjugated gold nanoparticles with plasma treatment against human YD-9 SCC cells in vitro based on results they have obtained with melanoma cells [102]. Promising results were seen in the combination of plasma therapy with traditional agents in melanoma treatment [103-105], which warrants further exploration for research on SCC in the future. This might also relate to combining plasma therapy with other physical modalities, such as pulsed electric fields, as recent reports have shown additive toxicity of both treatments in vitro $[101,106]$.

\section{Methods}

\subsection{Cell Culture}

The in vitro experiments were carried out using three human cell lines, namely A431 (ATCC: CRL-1555) and SCC13 (CVCL-4029), as malignant cutaneous squamous cell carcinoma cell lines, and non-malignant HaCaT keratinocytes. Cell culture was performed in Dulbecco's modified Eagle's medium (DMEM; Pan Biotech, Aidenbach, Germany), supplemented with 10\% fetal calf bovine serum (FCS), $2 \%$ glutamine, and 1\% penicillin and streptomycin (Sigma, Steinheim, Germany). For experiments, absolute cell counting was performed in a semi-automatic manner using acoustic focusing flow cytometry (Thermo Scientific, Waltham, USA). For 2D experiments, cells were resuspended in Roswell Park Memorial Institute 1640 (RPMI; Pan Biotech, Aidenbach, Germany) medium at $1.25 \times 10^{5}$ per $\mathrm{ml}$, and $750 \mu \mathrm{L}$ were added per well of a 24-well plate (Eppendorf, Hamburg, Germany; catalog number: 0030722116). The plates have a rim that can be filled with sterile water to protect the cultures from excessive evaporation and the 'edge effect'. For 3D tumor spheroid formation, $1 \times 10^{4}$ cells were seeded in ultra-low attachment plates (Nunclon Sphera; Thermo Scientific, Waltham, MA, USA) and centrifuged.

\subsection{Plasma Treatment and Cell Analysis}

Plasma treatment was done using high-purity (99.999\%) argon gas (Air Liquide, Paris, France) at two standard liters per minute to ignite the atmospheric pressure argon plasma jet kINPen (neoplas tools, Greifswald, Germany). The jet is well investigated and its operation and output parameters have been described in detail before [97]. The plasma treatment was performed in a standardized manner using an $x y z$-table (CNC Step, Gelfern, Germany), which fixed the plasma jet (distance from the nozzle to the liquid was $20 \mathrm{~mm}$ and kept constant) and operated the computer-driven treatment protocol. The support on which the tests are performed (e.g., conductive or dielectric surface) can influence the plasma characteristics and, therefore, the treatment [107]. The plasma treatment was done with the jet in non-conductive mode, hovering over a well plate of liquid containing the cells. The well plate was located on a plastic holder, which in turn was fixed on a grounded metal plate. Several 
plasma treatment times were employed. Evaporation was compensated by adding a pre-determined amount of double-distilled water. To analyze cytotoxic plasma effects in the 2D cultured cells in vitro, $1 \times 10^{4}$ cells were added in complete medium and allowed to adhere. After plasma treatment, resazurin (100 $\mu \mathrm{M}$; Alfa Aesar, Haverhill, MA, USA) was added 20 h later. After several hours of incubation, the dye was transformed via reduction reactions in metabolically active cells to the fluorescent resorufin. Fluorescence was determined using a multiplate reader (Tecan, Männedorf, Switzerland) at $\lambda_{\text {ex }} 535 \mathrm{~nm}$ and $\lambda_{\mathrm{em}} 590 \mathrm{~nm}$ and normalized to that of untreated control cells. Tumor spheroids were generated by adding $1 \times 10^{4}$ cells to ultra-low attachment plates (Nunc, Roskilde, Denmark), followed by the centrifugation of the plates at $1000 \times g$ and further incubation. To analyze cytotoxic plasma effects in the 3D cultured cells in vitro, sytox blue $(1 \mu \mathrm{M}$; Thermo Scientific, Waltham, USA) was added to the wells $24 \mathrm{~h}$ post-exposure. Sytox blue is a nuclear and chromosome counterstain. Because it is impermeant to live cells, it can be used as an indicator of dead cells within a population. The spheroids were subjected to high content imaging analysis (Operetta CLS; PerkinElmer, Hamburg, Germany) using a $5 x$ air objective (NA $=0.16$; Zeiss, Jena, Germany) to capture brightfield (BF) and sytox blue (SB) fluorescence at $\lambda_{\text {ex }} 365 \mathrm{~nm}$ and $\lambda_{\text {em }} 430-500 \mathrm{~nm}$. Data analysis of the sum intensity of sytox blue (SB) was done using Harmony 4.9 Software (PerkinElmer, Hamburg, Germany).

\subsection{Generation of UVB-Induced, SCC-Like Skin Lesions In Vivo}

Female 20-weeks-old HRS/J hairless mice weighing between 20 to $25 \mathrm{~g}$ were obtained from the central animal facility of the State University of São Paulo (USP). The animals were provided with access to water and food ad libitum, and handling was in accordance with the National Institution of Health guidelines for the welfare of experimental animals. The study was approved by the Research Ethics Committee (approval number 11633.2019.88) of the State University of Londrina, Paraná State, Brazil. To induce skin transformation, animals were exposed to UV irradiation, using the fluorescent lamp PHILIPSTL/12 40W UVB, which emits radiation from 270 to $400 \mathrm{~nm}$ with a maximum peak at around $313 \mathrm{~nm}$. The lamp was embedded in a $1.30 \mathrm{~m} \times 0.43 \mathrm{~m} \times 0.45 \mathrm{~m}$ box, where the mice were placed in cages $15 \mathrm{~cm}$ beneath the lamp. The boxes contained apparatus to ensure that the irradiation was directed toward the dorsal skin while simultaneously allowing for free movement of the animals. UVB output was measured using a Research Radiometer model IL-1700 (International Light, USA) with a radiometer sensor for UV (SED005) and UVB (SED240). A total of 73\% of the total UV irradiation under the experimental conditions was UVB. For the experiments, the animals were separated into four groups with five animals each: untreated (non-irradiated control), plasma alone, UVB alone, and UVB + plasma. The UVB irradiation (Figure 2A) started in the initiation phase, where mice from the UVB groups (Figure 2B) were exposed to $0.228 \mathrm{~J} / \mathrm{cm}^{2}$ of UV for $16 \mathrm{~min}, 5$ days a week, for 2 weeks. The animals then rested for 1 week, followed by a promotion phase, where they were irradiated with UVB every other day up to week 11 . On average, there were 1-3 lesions per animal. The kINPen plasma treatment started at the eighth week with $3 \mathrm{~min}$ treatment time per lesion every other day (alternating with UVB treatment). The animals in the plasma group (without UVB pre-treatment) received the same plasma treatment (Figure 2C). During the plasma treatment, the animals were anesthetized with ketamine/xylazine. This was not done because the plasma treatment was painful [14] but to reduce the stress the animals would have experienced during the prolonged immobilization period. Plasma treatment was performed on a heated and grounded surface. At the end of the 11th week, the animals were euthanized by cervical dislocation while still under anesthesia.

\subsection{Sample Collection}

Heparinized blood was collected by cardiac puncture and centrifuged at $1100 \times g$ to obtain blood plasma and erythrocytes. Blood plasma was stored at $-20{ }^{\circ} \mathrm{C}$. Erythrocytes were washed three times with $0.9 \% \mathrm{NaCl}$ and maintained at $4{ }^{\circ} \mathrm{C}$ in Alsever's solution. Cutaneous UVB-induced skin lesions were removed from the dorsal skin of UVB irradiated animals for histopathological and immunohistochemical analysis. Lesion-free, adjacent dorsal skin samples were removed and stored at 
$-80^{\circ} \mathrm{C}$ for total radical trapping antioxidant parameter (TRAP) assay. An equivalent area of tissue was collected in the control and plasma groups.

\subsection{Histopathological and Immunohistochemical Analysis}

Cutaneous lesions were fixed in 10\% neutral buffered-formalin, stored in $70 \%$ ethanol, and embedded in paraffin before sectioning. Sections of $5 \mu \mathrm{m}$ were cut and stained with hematoxylin and eosin (H\&E). The histopathological evaluation was made in a blinded study considering characteristics of transformed skin, such as epidermal thickness, follicular atrophy, keratin pearls, and the presence of atypical keratinocytes proliferating into the dermis [5]. For immunohistochemistry, $5 \mu \mathrm{m}$ sections were mounted on silanized slides, deparaffinized, rehydrated, immersed in $15 \mathrm{mmol} / \mathrm{L}$ citrate buffer ( $\mathrm{pH}$ 6.0), and subjected to heat-induced epitope retrieval using a vapor lock for $40 \mathrm{~min}$. The slides were rinsed with phosphate-buffered saline (PBS) and immersed in 3\% hydrogen peroxide for $30 \mathrm{~min}$ to block endogenous peroxidases. Non-specific protein binding was blocked with $3 \%$ BSA (bovine serum albumin) solution for $30 \mathrm{~min}$. The sections were then incubated with primary monoclonal antibodies targeted against catalase (1:50; Santa Cruz, Dallas, TX, USA), Ki-67 (1:100; Santa Cruz, Dallas, TX, USA), Nrf2 (1:250; Santa Cruz, Dallas, TX, USA), or 8-OHdG (1:100; Santa Cruz, Dallas, TX, USA) for $2 \mathrm{~h}$ at $37^{\circ} \mathrm{C}$ in a humid chamber. After incubation and washing, peroxidase-conjugated secondary anti-rabbit IgG (Sigma, Steinheim, Germany) was added for $1 \mathrm{~h}$ at room temperature, followed by their chromogenic detection, using 3,3'-diaminobenzidine (DAB; Sigma, Steinheim, Germany). The slides were counterstained with Harris's hematoxylin, dehydrated, and mounted with Permount (Biomeda, Foster City, CA, USA). Negative controls were done by omitting the primary antibody. The intensities of immunoreactivities against the primary antibody used were examined using a photomicroscope (Olympus BX41, Olympus Optical, Hamburg, Germany). For image analysis via ImageJ [108], the percentage of DAB staining was quantified in three fields of six different slides for each group. The average of the three fields was considered.

\subsection{Analysis of Local and Systemic Oxidative Stress Parameters}

Irradiated dorsal lesion-free skin samples from mice were defrosted and homogenized using an Ultra-Turrax homogenizer, containing $10 \mathrm{mg} / \mathrm{mL}$ or $50 \mathrm{mg} / \mathrm{mL}$ of tissue in buffer and centrifuged $\left(11,000 \times \mathrm{g}\right.$ for $15 \mathrm{~min}$ at $\left.4{ }^{\circ} \mathrm{C}\right)$. The $50 \mathrm{mg} / \mathrm{mL}$ supernatant was used for measurement of catalase activity [109] and reduced glutathione (GSH) content [110], while the $10 \mathrm{mg} / \mathrm{mL}$ supernatant was used to determine the total radical trapping antioxidant parameter (TRAP), as described before [111]. To analyze systemic GSH [110] and superoxide dismutase (SOD) activity [112], erythrocytes were washed and diluted in deionized water at ratios of 1:80 and 1:20, respectively. Blood plasma samples were defrosted and diluted at 1:2 for malondialdehyde (MDA) quantification via HPLC, indicating lipid peroxidation [113]. For normalization purposes, the total protein content was measured in erythrocytes (1:80) and tissue homogenate $(50 \mathrm{mg} / \mathrm{mL})[114,115]$.

\subsection{Statistical Analysis}

Graphing and statistical analysis were performed using prism 8.4.2 (GraphPad Software, San Diego, CA, USA). Mean and standard errors were calculated and graphed and statistical analysis was performed using an unpaired t-test, as indicated, or one-way or two-way analysis of variances (ANOVA), as indicated.

\section{Conclusions}

The aim was to test cold physical plasma as a means to target malignant lesions of the skin therapeutically. This was motivated by previous findings, suggesting an anticancer activity of plasma technology. Plasma treatment selectively limited carcinogenic progression of squamous cell carcinoma in vitro and in vivo via reduction of cell proliferation and modulation of redox balance. Moreover, it was identified that plasma treatment acted locally but not systemically, at least in terms of oxidative 
and antioxidative parameters that are tightly linked to the primary biological mechanism of plasma systems, reactive oxygen, and nitrogen species. Furthermore, reducing the harmful effects of existing SCC therapies may be achieved by combining plasma treatment with existing SCC therapies to enhance their clinical efficacy, an increasingly important approach in oncology.

Author Contributions: Conceptualization, A.L.C. and S.B.; methodology, T.N., L.J.S., F.P.B., and J.K.B.; validation, G.P.-M., T.N., L.J.S., F.P.B., J.K.B., S.K.S., J.B., A.S. and S.E.; formal analysis, G.P.-M., T.N., L.J.S., F.P.B., J.K.B., J.B. and S.B.; investigation, G.P.-M., T.N., L.J.S., F.P.B., J.K.B., S.K.S. and J.B.; resources, A.L.C. and S.B.; data curation, G.P.-M. and S.B.; writing - original draft preparation, G.P.-M. and S.B.; writing-review and editing, all authors; visualization, G.P.-M. and S.B.; supervision, K.-D.W., T.v.W. and S.B.; project administration, R.K.G., A.L.C. and S.B.; funding acquisition, K.-D.W., T.v.W., S.E., A.L.C. and S.B. All authors have read and agreed to the published version of the manuscript.

Funding: K.D.W., T.v.W., and S.B. received funding by the German Federal Ministry of Education and Research, grant numbers 03Z22DN11 and 03Z22Di1. S.E. is supported by the Damp Foundation. S.K.S., J.B., S.E., T.v.W., and S.B. received funding by the European Social Fund (ESF) and the Ministry of Education, Science, and Culture of Mecklenburg-West Pomerania, Germany (grant numbers ESF/14-BM-A55-0001/18 and ESF/14-BM-A55-0006/18).

Acknowledgments: The authors gratefully acknowledge technical support by Felix Niessner.

Conflicts of Interest: The authors declare that there is no conflict of interest regarding the publication of this paper.

\section{References}

1. Leiter, U.; Eigentler, T.; Garbe, C. Epidemiology of skin cancer. In Sunlight, Vitamin D and Skin Cancer; Springer: New York, NY, USA, 2014; pp. 120-140.

2. Voiculescu, V.; Calenic, B.; Ghita, M.; Lupu, M.; Caruntu, A.; Moraru, L.; Voiculescu, S.; Ion, A.; Greabu, M.; Ishkitiev, N.J.D.M. From normal skin to squamous cell carcinoma: A quest for novel biomarkers. Dis. Markers 2016, 2016, 4517492. [CrossRef] [PubMed]

3. Kasper, M.; Jaks, V.; Hohl, D.; Toftgård, R. Basal cell carcinoma-Molecular biology and potential new therapies. J. Clin. Investig. 2012, 122, 455-463. [CrossRef] [PubMed]

4. Walling, H.W.; Fosko, S.W.; Geraminejad, P.A.; Whitaker, D.C.; Arpey, C.J.J.C.; Reviews, M. Aggressive basal cell carcinoma: Presentation, pathogenesis, and management. Cancer Metastasis Rev. 2004, 23, 389-402. [CrossRef]

5. Xu, Y.G.; Aylward, J.L.; Swanson, A.M.; Spiegelman, V.S.; Vanness, E.R.; Teng, J.M.; Snow, S.N.; Wood, G.S. Nonmelanoma skin cancers: Basal cell and squamous cell carcinomas. In Abeloff's Clinical Oncology; Elsevier: Amsterdam, The Netherlands, 2020; pp. 1052-1073.e8.

6. Didona, D.; Paolino, G.; Bottoni, U.; Cantisani, C.J.B. Non melanoma skin cancer pathogenesis overview. Biomedicines 2018, 6, 6. [CrossRef] [PubMed]

7. Kallini, J.R.; Hamed, N.; Khachemoune, A. Squamous cell carcinoma of the skin: Epidemiology, classification, management, and novel trends. Int. J. Dermatol. 2015, 54, 130-140. [CrossRef] [PubMed]

8. Love, W.E.; Bernhard, J.D.; Bordeaux, J.S. Topical imiquimod or fluorouracil therapy for basal and squamous cell carcinoma: A systematic review. Arch. Dermatol. 2009, 145, 1431-1438. [CrossRef] [PubMed]

9. Samarasinghe, V.; Madan, V.; Lear, J.T. Management of high-risk squamous cell carcinoma of the skin. Expert Rev. Anticancer Ther. 2011, 11, 763-769. [CrossRef]

10. Von Woedtke, T.; Reuter, S.; Masur, K.; Weltmann, K.D. Plasmas for medicine. Phys. Rep. 2013, 530, $291-320$. [CrossRef]

11. Graves, D.B. Low temperature plasma biomedicine: A tutorial review. Phys. Plasmas 2014, 21. [CrossRef]

12. Kaushik, N.K.; Ghimire, B.; Li, Y.; Adhikari, M.; Veerana, M.; Kaushik, N.; Jha, N.; Adhikari, B.; Lee, S.J.; Masur, K.; et al. Biological and medical application of plasma-activated media, water and solutions. Biol. Chem. 2018. [CrossRef]

13. Mitra, S.; Nguyen, L.N.; Akter, M.; Park, G.; Choi, E.H.; Kaushik, N.K. Impact of ros generated by chemical, physical, and plasma techniques on cancer attenuation. Cancers 2019, 11, 1030. [CrossRef] [PubMed]

14. Bekeschus, S.; Schmidt, A.; Weltmann, K.-D.; von Woedtke, T. The plasma jet kinpen-A powerful tool for wound healing. Clin. Plas. Med. 2016, 4, 19-28. [CrossRef] 
15. Lin, A.; Gorbanev, Y.; De Backer, J.; Van Loenhout, J.; Van Boxem, W.; Lemiere, F.; Cos, P.; Dewilde, S.; Smits, E.; Bogaerts, A. Non-thermal plasma as a unique delivery system of short-lived reactive oxygen and nitrogen species for immunogenic cell death in melanoma cells. Adv. Sci. 2019, 6, 1802062. [CrossRef] [PubMed]

16. Bekeschus, S.; Clemen, R.; Niessner, F.; Sagwal, S.K.; Freund, E.; Schmidt, A. Medical gas plasma jet technology targets murine melanoma in an immunogenic fashion. Adv. Sci. 2020, 7, 1903438. [CrossRef]

17. Binenbaum, Y.; Ben-David, G.; Gil, Z.; Slutsker, Y.Z.; Ryzhkov, M.A.; Felsteiner, J.; Krasik, Y.E.; Cohen, J.T. Cold atmospheric plasma, created at the tip of an elongated flexible capillary using low electric current, can slow the progression of melanoma. PLOS ONE 2017, 12, e0169457. [CrossRef]

18. Metelmann, H.-R.; Nedrelow, D.S.; Seebauer, C.; Schuster, M.; von Woedtke, T.; Weltmann, K.-D.; Kindler, S.; Metelmann, P.H.; Finkelstein, S.E.; Von Hoff, D.D.; et al. Head and neck cancer treatment and physical plasma. Clin. Plas. Med. 2015, 3, 17-23. [CrossRef]

19. Metelmann, H.-R.; Seebauer, C.; Miller, V.; Fridman, A.; Bauer, G.; Graves, D.B.; Pouvesle, J.-M.; Rutkowski, R.; Schuster, M.; Bekeschus, S.; et al. Clinical experience with cold plasma in the treatment of locally advanced head and neck cancer. Clin. Plas. Med. 2018, 9, 6-13. [CrossRef]

20. Bekeschus, S.; Schmidt, A.; Kramer, A.; Metelmann, H.R.; Adler, F.; von Woedtke, T.; Niessner, F.; Weltmann, K.D.; Wende, K. High throughput image cytometry micronucleus assay to investigate the presence or absence of mutagenic effects of cold physical plasma. Environ. Mol. Mutagen. 2018, 59, 268-277. [CrossRef]

21. Schmidt, A.; Woedtke, T.V.; Stenzel, J.; Lindner, T.; Polei, S.; Vollmar, B.; Bekeschus, S. One year follow-up risk assessment in skh-1 mice and wounds treated with an argon plasma jet. Int. J. Mol. Sci. 2017, 18, 868. [CrossRef]

22. Boxhammer, V.; Li, Y.F.; Koritzer, J.; Shimizu, T.; Maisch, T.; Thomas, H.M.; Schlegel, J.; Morfill, G.E.; Zimmermann, J.L. Investigation of the mutagenic potential of cold atmospheric plasma at bactericidal dosages. Mutat. Res. 2013, 753, 23-28. [CrossRef]

23. Rutkowski, R.; Daeschlein, G.; von Woedtke, T.; Smeets, R.; Gosau, M.; Metelmann, H.R. Long-term risk assessment for medical application of cold atmospheric pressure plasma. Diagnostics 2020, 10, 210. [CrossRef] [PubMed]

24. Metelmann, H.-R.; Vu, T.T.; Do, H.T.; Le, T.N.B.; Hoang, T.H.A.; Phi, T.T.T.; Luong, T.M.L.; Doan, V.T.; Nguyen, T.T.H.; Nguyen, T.H.M.; et al. Scar formation of laser skin lesions after cold atmospheric pressure plasma (cap) treatment: A clinical long term observation. Clin. Plas. Med. 2013, 1, 30-35. [CrossRef]

25. Schuster, M.; Rutkowski, R.; Hauschild, A.; Shojaei, R.K.; von Woedtke, T.; Rana, A.; Bauer, G.; Metelmann, P.; Seebauer, C. Side effects in cold plasma treatment of advanced oral cancer-Clinical data and biological interpretation. Clin. Plas. Med. 2018, 10, 9-15. [CrossRef]

26. Xiang, L.; Xu, X.; Zhang, S.; Cai, D.; Dai, X. Cold atmospheric plasma conveys selectivity on triple negative breast cancer cells both in vitro and in vivo. Free Radic. Biol. Med. 2018, 124, 205-213. [CrossRef]

27. Canal, C.; Fontelo, R.; Hamouda, I.; Guillem-Marti, J.; Cvelbar, U.; Ginebra, M.P. Plasma-induced selectivity in bone cancer cells death. Free Radic. Biol. Med. 2017, 110, 72-80. [CrossRef]

28. Pai, K.K.; Singarapu, K.; Jacob, J.D.; Madihally, S.V. Dose dependent selectivity and response of different types of mammalian cells to surface dielectric barrier discharge (SDBD) plasma. Plasma Process. Polym. 2015, 12, 666-677. [CrossRef]

29. Guerrero-Preston, R.; Ogawa, T.; Uemura, M.; Shumulinsky, G.; Valle, B.L.; Pirini, F.; Ravi, R.; Sidransky, D.; Keidar, M.; Trink, B. Cold atmospheric plasma treatment selectively targets head and neck squamous cell carcinoma cells. Int. J. Mol. Med. 2014, 34, 941-946. [CrossRef]

30. Brany, D.; Dvorska, D.; Halasova, E.; Skovierova, H. Cold atmospheric plasma: A powerful tool for modern medicine. Int. J. Mol. Sci. 2020, 21, 2932. [CrossRef]

31. Dai, X.; Bazaka, K.; Richard, D.J.; Thompson, E.R.W.; Ostrikov, K.K. The emerging role of gas plasma in oncotherapy. Trends Biotechnol. 2018, 36, 1183-1198. [CrossRef]

32. Privat-Maldonado, A.; Bengtson, C.; Razzokov, J.; Smits, E.; Bogaerts, A. Modifying the tumour microenvironment: Challenges and future perspectives for anticancer plasma treatments. Cancers 2019, 11, 1920. [CrossRef] 
33. Carrara, I.M.; Melo, G.P.; Bernardes, S.S.; Neto, F.S.; Ramalho, L.N.Z.; Marinello, P.C.; Luiz, R.C.; Cecchini, R.; Cecchini, A.L. Looking beyond the skin: Cutaneous and systemic oxidative stress in uvb-induced squamous cell carcinoma in hairless mice. J. Photochem. Photobiol. B 2019, 195, 17-26. [CrossRef] [PubMed]

34. Komaravelli, N.; Tian, B.; Ivanciuc, T.; Mautemps, N.; Brasier, A.R.; Garofalo, R.P.; Casola, A. Respiratory syncytial virus infection down-regulates antioxidant enzyme expression by triggering deacetylation-proteasomal degradation of nrf2. Free Radic. Biol. Med. 2015, 88, 391-403. [CrossRef]

35. Bekeschus, S.; Schutz, C.S.; Niessner, F.; Wende, K.; Weltmann, K.D.; Gelbrich, N.; von Woedtke, T.; Schmidt, A.; Stope, M.B. Elevated h2ax phosphorylation observed with kinpen plasma treatment is not caused by ros-mediated DNA damage but is the consequence of apoptosis. Oxid. Med. Cell. Longev. 2019, 2019, 8535163. [CrossRef]

36. Schmidt, A.; von Woedtke, T.; Vollmar, B.; Hasse, S.; Bekeschus, S. Nrf2 signaling and inflammation are key events in physical plasma-spurred wound healing. Theranostics 2019, 9, 1066-1084. [CrossRef] [PubMed]

37. Metelmann, H.-R.; von Woedtke, T.; Bussiahn, R.; Weltmann, K.-D.; Rieck, M.; Khalili, R.; Podmelle, F.; Waite, P.D. Experimental recovery of CO2-laser skin lesions by plasma stimulation. Am. J. Cosmet. Surg. 2012, 29, 52-56. [CrossRef]

38. Lademann, J.; Richter, H.; Alborova, A.; Humme, D.; Patzelt, A.; Kramer, A.; Weltmann, K.D.; Hartmann, B.; Ottomann, C.; Fluhr, J.W.; et al. Risk assessment of the application of a plasma jet in dermatology. J. Biomed. Opt. 2009, 14, 054025. [CrossRef] [PubMed]

39. Lademann, J.; Ulrich, C.; Patzelt, A.; Richter, H.; Kluschke, F.; Klebes, M.; Lademann, O.; Kramer, A.; Weltmann, K.D.; Lange-Asschenfeldt, B. Risk assessment of the application of tissue-tolerable plasma on human skin. Clin. Plas. Med. 2013, 1, 5-10. [CrossRef]

40. Lademann, O.; Kramer, A.; Richter, H.; Patzelt, A.; Meinke, M.C.; Roewert-Huber, J.; Czaika, V.; Weltmann, K.D.; Hartmann, B.; Koch, S. Antisepsis of the follicular reservoir by treatment with tissue-tolerable plasma (ttp). Laser Phys. Lett. 2011, 8, 313-317. [CrossRef]

41. Cranmer, L.D.; Engelhardt, C.; Morgan, S.S. Treatment of unresectable and metastatic cutaneous squamous cell carcinoma. Oncologist 2010, 15, 1320-1328. [CrossRef]

42. Karia, P.S.; Han, J.; Schmults, C.D. Cutaneous squamous cell carcinoma: Estimated incidence of disease, nodal metastasis, and deaths from disease in the united states, 2012. J. Am. Acad. Dermatol. 2013, 68, 957-966. [CrossRef]

43. Apalla, Z.; Lallas, A.; Sotiriou, E.; Lazaridou, E.; Ioannides, D. Epidemiological trends in skin cancer. Dermatol. Pract. Concept. 2017, 7, 1-6. [CrossRef] [PubMed]

44. D'Orazio, J.; Jarrett, S.; Amaro-Ortiz, A.; Scott, T. Uv radiation and the skin. Int. J. Mol. Sci. 2013, 14, $12222-12248$. [CrossRef] [PubMed]

45. Wolfle, U.; Esser, P.R.; Simon-Haarhaus, B.; Martin, S.F.; Lademann, J.; Schempp, C.M. Uvb-induced DNA damage, generation of reactive oxygen species, and inflammation are effectively attenuated by the flavonoid luteolin in vitro and in vivo. Free Radic. Biol. Med. 2011, 50, 1081-1093. [CrossRef] [PubMed]

46. Fu, T.; Aasi, S.Z.; Hollmig, S.T. Management of high-risk squamous cell carcinoma of the skin. Curr. Treat. Options Oncol. 2016, 17, 34. [CrossRef] [PubMed]

47. Kang, S.U.; Cho, J.H.; Chang, J.W.; Shin, Y.S.; Kim, K.I.; Park, J.K.; Yang, S.S.; Lee, J.S.; Moon, E.; Lee, K.; et al. Nonthermal plasma induces head and neck cancer cell death: The potential involvement of mitogen-activated protein kinase-dependent mitochondrial reactive oxygen species. Cell Death Dis. 2014, 5, e1056. [CrossRef]

48. Griffith, B.; Pendyala, S.; Hecker, L.; Lee, P.J.; Natarajan, V.; Thannickal, V.J. Nox enzymes and pulmonary disease. Antioxid. Redox Signal. 2009, 11, 2505-2516. [CrossRef] [PubMed]

49. Pick, E.; Mizel, D. Rapid microassays for the measurement of superoxide and hydrogen-peroxide production by macrophages in culture using an automatic enzyme-immunoassay reader. J. Immunol. Methods 1981, 46, 211-226. [CrossRef]

50. Zelko, I.N.; Mariani, T.J.; Folz, R.J. Superoxide dismutase multigene family: A comparison of the cuzn-sod (sod1), mn-sod (sod2), and ec-sod (sod3) gene structures, evolution, and expression. Free Radic. Biol. Med. 2002, 33, 337-349. [CrossRef]

51. Kim, S.Y.; Kim, H.J.; Kang, S.U.; Kim, Y.E.; Park, J.K.; Shin, Y.S.; Kim, Y.S.; Lee, K.; Kim, C.H. Non-thermal plasma induces akt degradation through turn-on the mul1 e3 ligase in head and neck cancer. Oncotarget 2015, 6, 33382-33396. [CrossRef] [PubMed] 
52. Mizuno, K.; Shirakawa, Y.; Sakamoto, T.; Ishizaki, H.; Nishijima, Y.; Ono, R. Plasma-induced suppression of recurrent and reinoculated melanoma tumors in mice. IEEE Trans. Radiat. Plasma Med Sci. 2018, 2, 353-359. [CrossRef]

53. Mizuno, K.; Yonetamari, K.; Shirakawa, Y.; Akiyama, T.; Ono, R. Anti-tumor immune response induced by nanosecond pulsed streamer discharge in mice. J. Phys. D Appl. Phys. 2017, 50, 12LT01. [CrossRef]

54. Kim, H.; Casta, A.; Tang, X.; Luke, C.T.; Kim, A.L.; Bickers, D.R.; Athar, M.; Christiano, A.M. Loss of hairless confers susceptibility to uvb-induced tumorigenesis via disruption of nf-kappab signaling. PLoS ONE 2012, 7, e39691. [CrossRef] [PubMed]

55. Valavanidis, A.; Vlachogianni, T.; Fiotakis, C. 8-hydroxy-2'-deoxyguanosine (8-OHdG): A critical biomarker of oxidative stress and carcinogenesis. J. Environ. Sci. Health Part C 2009, 27, 120-139. [CrossRef] [PubMed]

56. Arjunan, K.P.; Sharma, V.K.; Ptasinska, S. Effects of atmospheric pressure plasmas on isolated and cellular DNA-a review. Int. J. Mol. Sci. 2015, 16, 2971-3016. [CrossRef] [PubMed]

57. Chang, J.W.; Kang, S.U.; Shin, Y.S.; Kim, K.I.; Seo, S.J.; Yang, S.S.; Lee, J.S.; Moon, E.; Baek, S.J.; Lee, K.; et al. Non-thermal atmospheric pressure plasma induces apoptosis in oral cavity squamous cell carcinoma: Involvement of DNA-damage-triggering sub-G(1) arrest via the atm/p53 pathway. Arch. Biochem. Biophys. 2014, 545, 133-140. [CrossRef]

58. Han, X.; Klas, M.; Liu, Y.Y.; Stack, M.S.; Ptasinska, S. DNA damage in oral cancer cells induced by nitrogen atmospheric pressure plasma jets. Appl. Phys. Lett. 2013, 102. [CrossRef]

59. Kalghatgi, S.; Azizkhan-Clifford, J. DNA damage in mammalian cells by atmospheric pressure microsecond-pulsed dielectric barrier discharge plasma is not mediated via lipid peroxidation. Plasma Med. 2011, 1, 167-177. [CrossRef]

60. Turrini, E.; Laurita, R.; Simoncelli, E.; Stancampiano, A.; Catanzaro, E.; Calcabrini, C.; Carulli, G.; Rousseau, M.; Gherardi, M.; Maffei, F.; et al. Plasma-activated medium as an innovative anticancer strategy: Insight into its cellular and molecular impact on in vitro leukemia cells. Plasma Process. Polym. 2020. [CrossRef]

61. Kluge, S.; Bekeschus, S.; Bender, C.; Benkhai, H.; Sckell, A.; Below, H.; Stope, M.B.; Kramer, A. Investigating the mutagenicity of a cold argon-plasma jet in an HET-MN model. PLoS ONE 2016, 11, e0160667. [CrossRef]

62. Cleaver, J.E. Gammah2ax: Biomarker of damage or functional participant in DNA repair "all that glitters is not gold!". Photochem. Photobiol. 2011, 87, 1230-1239. [CrossRef]

63. Schmidt, A.; Bekeschus, S.; Jarick, K.; Hasse, S.; von Woedtke, T.; Wende, K. Cold physical plasma modulates p53 and mitogen-activated protein kinase signaling in keratinocytes. Oxid. Med. Cell. Longev. 2019, 2019, 1-16. [CrossRef] [PubMed]

64. Balzer, J.; Demir, E.; Kogelheide, F.; Fuchs, P.C.; Stapelmann, K.; Opländer, C. Cold atmospheric plasma (CAP) differently affects migration and differentiation of keratinocytes via hydrogen peroxide and nitric oxide-related products. Clin. Plas. Med. 2019, 13, 1-8. [CrossRef]

65. Hasse, S.; Hahn, O.; Kindler, S.; von Woedtke, T.; Metelmann, H.-R.; Masur, K. Atmospheric pressure plasma jet application on human oral mucosa modulates tissue regeneration. Plasma Med. 2014, 4, 117-129. [CrossRef]

66. Stacy, D.R.; Ely, K.; Massion, P.P.; Yarbrough, W.G.; Hallahan, D.E.; Sekhar, K.R.; Freeman, M.L. Increased expression of nuclear factor E2 p45-related factor 2 (NRF2) in head and neck squamous cell carcinomas. Head Neck 2006, 28, 813-818. [CrossRef] [PubMed]

67. Schafer, M.; Werner, S. Nrf2-A regulator of keratinocyte redox signaling. Free Radic. Biol. Med. 2015, 88, 243-252. [CrossRef] [PubMed]

68. Ashino, T.; Yamanaka, R.; Yamamoto, M.; Shimokawa, H.; Sekikawa, K.; Iwakura, Y.; Shioda, S.; Numazawa, S.; Yoshida, T. Negative feedback regulation of lipopolysaccharide-induced inducible nitric oxide synthase gene expression by heme oxygenase-1 induction in macrophages. Mol. Immunol. 2008, 45, 2106-2115. [CrossRef]

69. Hayes, J.D.; McMahon, M. Nrf2 and keap1 mutations: Permanent activation of an adaptive response in cancer. Trends Biochem. Sci. 2009, 34, 176-188. [CrossRef]

70. Salazar, M.; Rojo, A.I.; Velasco, D.; de Sagarra, R.M.; Cuadrado, A. Glycogen synthase kinase-3beta inhibits the xenobiotic and antioxidant cell response by direct phosphorylation and nuclear exclusion of the transcription factor Nrf2. J. Biol. Chem. 2006, 281, 14841-14851. [CrossRef]

71. Ramireddy, L.; Lai, C.H.; Low, B.S.; Li, C.; Hsieh, J.H.; Lee, J.W.; Wu, H.Y. Induction of apoptosis by cold atmospheric pressure plasma for oral squamous cell carcinoma cells. Plasma Med. 2018, 8, 411-418. [CrossRef] 
72. Welz, C.; Emmert, S.; Canis, M.; Becker, S.; Baumeister, P.; Shimizu, T.; Morfill, G.E.; Harreus, U.; Zimmermann, J.L. Cold atmospheric plasma: A promising complementary therapy for squamous head and neck cancer. PLOS ONE 2015, 10, e0141827. [CrossRef]

73. Sato, K.; Shi, L.; Ito, F.; Ohara, Y.; Motooka, Y.; Tanaka, H.; Mizuno, M.; Hori, M.; Hirayama, T.; Hibi, H.; et al. Nonthermal plasma specifically kills oral squamous cell carcinoma cells in a catalytic Fe(II)dependent manner. J. Clin. Biochem. Nutr. 2019, 65, 8-15. [CrossRef] [PubMed]

74. Schmidt, A.; Bekeschus, S. Redox for repair: Cold physical plasmas and nrf2 signaling promoting wound healing. Antioxidants 2018, 7, 146. [CrossRef] [PubMed]

75. Schmidt, A.; Dietrich, S.; Steuer, A.; Weltmann, K.D.; von Woedtke, T.; Masur, K.; Wende, K. Non-thermal plasma activates human keratinocytes by stimulation of antioxidant and phase ii pathways. J. Biol. Chem. 2015, 290, 6731-6750. [CrossRef]

76. Bekeschus, S.; Freund, E.; Wende, K.; Gandhirajan, R.K.; Schmidt, A. Hmox1 upregulation is a mutual marker in human tumor cells exposed to physical plasma-derived oxidants. Antioxidants 2018, 7, 151. [CrossRef] [PubMed]

77. Schmidt, A.; Rodder, K.; Hasse, S.; Masur, K.; Toups, L.; Lillig, C.H.; von Woedtke, T.; Wende, K.; Bekeschus, S. Redox-regulation of activator protein 1 family members in blood cancer cell lines exposed to cold physical plasma-treated medium. Plasma Process. Polym. 2016, 13, 1179-1188. [CrossRef]

78. Van der Paal, J.; Hong, S.H.; Yusupov, M.; Gaur, N.; Oh, J.S.; Short, R.D.; Szili, E.J.; Bogaerts, A. How membrane lipids influence plasma delivery of reactive oxygen species into cells and subsequent DNA damage: An experimental and computational study. Phys. Chem. Chem. Phys. 2019, 21, 19327-19341. [CrossRef] [PubMed]

79. Van der Paal, J.; Neyts, E.C.; Verlackt, C.C.W.; Bogaerts, A. Effect of lipid peroxidation on membrane permeability of cancer and normal cells subjected to oxidative stress. Chem. Sci. 2016, 7, 489-498. [CrossRef] [PubMed]

80. Van der Paal, J.; Verheyen, C.; Neyts, E.C.; Bogaerts, A. Hampering effect of cholesterol on the permeation of reactive oxygen species through phospholipids bilayer: Possible explanation for plasma cancer selectivity. Sci. Rep. 2017, 7, 39526. [CrossRef]

81. Yan, D.; Talbot, A.; Nourmohammadi, N.; Sherman, J.H.; Cheng, X.; Keidar, M. Toward understanding the selective anticancer capacity of cold atmospheric plasma-A model based on aquaporins (review). Biointerphases 2015, 10, 040801. [CrossRef]

82. Yan, D.Y.; Xiao, H.J.; Zhu, W.; Nourmohammadi, N.; Zhang, L.G.; Bian, K.; Keidar, M. The role of aquaporins in the anti-glioblastoma capacity of the cold plasma-stimulated medium. J. Phys. D Appl. Phys. 2017, 50. [CrossRef]

83. Yusupov, M.; Yan, D.Y.; Cordeiro, R.M.; Bogaerts, A. Atomic scale simulation of $\mathrm{H} 2 \mathrm{O} 2$ permeation through aquaporin: Toward the understanding of plasma cancer treatment. J. Phys. D Appl. Phys. 2018, 51. [CrossRef]

84. Ellerweg, D.; Benedikt, J.; von Keudell, A.; Knake, N.; Schulz-von der Gathen, V. Characterization of the effluent of a $\mathrm{He} / \mathrm{O} 2$ microscale atmospheric pressure plasma jet by quantitative molecular beam mass spectrometry. New J. Phys. 2010, 12, 013021. [CrossRef]

85. Gaens, W.V.; Iseni, S.; Schmidt-Bleker, A.; Weltmann, K.D.; Reuter, S.; Bogaerts, A. Numerical analysis of the effect of nitrogen and oxygen admixtures on the chemistry of an argon plasma jet operating at atmospheric pressure. New J. Phys. 2015, 17, 033003. [CrossRef]

86. Benedikt, J.; Schroder, D.; Schneider, S.; Willems, G.; Pajdarova, A.; Vlcek, J.; Schulz-von der Gathen, V. Absolute $\mathrm{OH}$ and $\mathrm{O}$ radical densities in effluent of a $\mathrm{He} / \mathrm{H} 2 \mathrm{O}$ micro-scaled atmospheric pressure plasma jet. Plasma Sources Sci. T. 2016, 25, 045013. [CrossRef]

87. Knake, N.; Reuter, S.; Niemi, K.; Schulz-von der Gathen, V.; Winter, J. Absolute atomic oxygen density distributions in the effluent of a microscale atmospheric pressure plasma jet. J. Phys. D Appl. Phys. 2008, 41, 194006. [CrossRef]

88. Lu, X.; Naidis, G.V.; Laroussi, M.; Reuter, S.; Graves, D.B.; Ostrikov, K. Reactive species in non-equilibrium atmospheric-pressure plasmas: Generation, transport, and biological effects. Phys. Rep. Rev. Sect. Phys. Lett. 2016, 630, 1-84. [CrossRef]

89. Bauer, G. The synergistic effect between hydrogen peroxide and nitrite, two long-lived molecular species from cold atmospheric plasma, triggers tumor cells to induce their own cell death. Redox Biol. 2019, 26, 101291. [CrossRef] [PubMed] 
90. Kim, Y.H.; Hong, Y.J.; Baik, K.Y.; Kwon, G.C.; Choi, J.J.; Cho, G.S.; Uhm, H.S.; Kim, D.Y.; Choi, E.H. Measurement of reactive hydroxyl radical species inside the biosolutions during non-thermal atmospheric pressure plasma jet bombardment onto the solution. Plasma Chem. Plasma Process. 2014, 34, 457-472. [CrossRef]

91. Lukes, P.; Dolezalova, E.; Sisrova, I.; Clupek, M. Aqueous-phase chemistry and bactericidal effects from an air discharge plasma in contact with water: Evidence for the formation of peroxynitrite through a pseudo-second-order post-discharge reaction of H2O2 and HNO2. Plasma Sources Sci. T. 2014, $23,015019$. [CrossRef]

92. Liu, D.X.; Sun, B.W.; Iza, F.; Xu, D.H.; Wang, X.H.; Rong, M.Z.; Kong, M.G. Main species and chemical pathways in cold atmospheric-pressure ar + h2o plasmas. Plasma Sources Sci. T. 2017, 26. [CrossRef]

93. Uchiyama, H.; Zhao, Q.L.; Hassan, M.A.; Andocs, G.; Nojima, N.; Takeda, K.; Ishikawa, K.; Hori, M.; Kondo, T. Epr-spin trapping and flow cytometric studies of free radicals generated using cold atmospheric argon plasma and x-ray irradiation in aqueous solutions and intracellular milieu. PLoS ONE 2015, 10, e0136956. [CrossRef] [PubMed]

94. Kang, S.U.; Seo, S.J.; Kim, Y.S.; Shin, Y.S.; Koh, Y.W.; Lee, C.M.; Yang, S.S.; Lee, J.S.; Moon, E.; Kang, H.; et al. Comparative effects of non-thermal atmospheric pressure plasma on migration and invasion in oral squamous cell cancer, by gas type. Yonsei Med. J. 2017, 58, 272-281. [CrossRef] [PubMed]

95. Lee, J.H.; Om, J.Y.; Kim, Y.H.; Kim, K.M.; Choi, E.H.; Kim, K.N. Selective killing effects of cold atmospheric pressure plasma with no induced dysfunction of epidermal growth factor receptor in oral squamous cell carcinoma. PLoS ONE 2016, 11, e0150279. [CrossRef] [PubMed]

96. Schmidt-Bleker, A.; Bansemer, R.; Reuter, S.; Weltmann, K.-D. How to produce an nox- instead of ox-based chemistry with a cold atmospheric plasma jet. Plasma Process. Polym. 2016, 13, 1120-1127. [CrossRef]

97. Reuter, S.; von Woedtke, T.; Weltmann, K.D. The kinpen-a review on physics and chemistry of the atmospheric pressure plasma jet and its applications. J. Phys. D Appl. Phys. 2018, 51. [CrossRef]

98. Bauer, G. Targeting protective catalase of tumor cells with cold atmospheric plasma- activated medium (pam). Anticancer Agents Med. Chem. 2018, 18, 784-804. [CrossRef]

99. Girard, P.M.; Arbabian, A.; Fleury, M.; Bauville, G.; Puech, V.; Dutreix, M.; Sousa, J.S. Synergistic effect of h2o2 and no2 in cell death induced by cold atmospheric he plasma. Sci. Rep. 2016, 6, 29098. [CrossRef]

100. Bussiahn, R.; Lembke, N.; Gesche, R.; von Woedtke, T.; Weltmann, K.-D. Plasma sources for biomedical applications. Hyg. Med. 2013, 38, 212-216.

101. Wolff, C.M.; Kolb, J.F.; Weltmann, K.-D.; von Woedtke, T.; Bekeschus, S. Combination treatment with cold physical plasma and pulsed electric fields augments ros production and cytotoxicity in lymphoma. Cancers 2020, 12, 845. [CrossRef]

102. Kim, G.C.; Kim, G.J.; Park, S.R.; Jeon, S.M.; Seo, H.J.; Iza, F.; Lee, J.K. Air plasma coupled with antibody-conjugated nanoparticles: A new weapon against cancer. J. Phys. D Appl. Phys. 2009, 42, 032005. [CrossRef]

103. Pasqual-Melo, G.; Sagwal, S.K.; Freund, E.; Gandhirajan, R.K.; Frey, B.; von Woedtke, T.; Gaipl, U.; Bekeschus, S. Combination of gas plasma and radiotherapy has immunostimulatory potential and additive toxicity in murine melanoma cells in vitro. Int. J. Mol. Sci. 2020, 21, 1379. [CrossRef] [PubMed]

104. Shaw, P.; Kumar, N.; Hammerschmid, D.; Privat-Maldonado, A.; Dewilde, S.; Bogaerts, A. Synergistic effects of melittin and plasma treatment: A promising approach for cancer therapy. Cancers 2019, 11, 1109. [CrossRef] [PubMed]

105. Sagwal, S.K.; Pasqual-Melo, G.; Bodnar, Y.; Gandhirajan, R.K.; Bekeschus, S. Combination of chemotherapy and physical plasma elicits melanoma cell death via upregulation of SLC22A16. Cell Death Dis. 2018, 9, 1179. [CrossRef] [PubMed]

106. Chung, T.H.; Stancampiano, A.; Sklias, K.; Gazeli, K.; Andre, F.M.; Dozias, S.; Douat, C.; Pouvesle, J.M.; Santos Sousa, J.; Robert, E.; et al. Cell electropermeabilisation enhancement by non-thermal-plasma-treated pbs. Cancers 2020, 12, 219. [CrossRef] [PubMed]

107. Stancampiano, A.; Chung, T.H.; Dozias, S.; Pouvesle, J.M.; Mir, L.M.; Robert, E. Mimicking of human body electrical characteristic for easier translation of plasma biomedical studies to clinical applications. IEEE Trans. Radiat. Plasma Med Sci. 2020, 4, 335-342. [CrossRef]

108. Yuan, J.X.; Munson, J.M. Quantitative immunohistochemistry of the cellular microenvironment in patient glioblastoma resections. J. Vis. Exp. 2017. [CrossRef] 
109. Aebi, H. Catalase in vitro. In Methods in Enzymology; Elsevier: Amsterdam, The Netherlands, 1984; Volume 105, pp. 121-126.

110. Tietze, F. Enzymic method for quantitative determination of nanogram amounts of total and oxidized glutathione: Applications to mammalian blood and other tissues. Anal. Biochem. 1969, 27, 502-522. [CrossRef]

111. Terra, V.A.; Souza-Neto, F.P.; Pereira, R.C.; Xavier Da Silva, T.N.; Ramalho, L.N.; Luiz, R.C.; Cecchini, R.; Cecchini, A.L. Nitric oxide is responsible for oxidative skin injury and modulation of cell proliferation after 24 hours of uvb exposures. Free Radic. Res. 2012, 46, 872-882. [CrossRef]

112. Marklund, S.; Marklund, G. Involvement of the superoxide anion radical in the autoxidation of pyrogallol and a convenient assay for superoxide dismutase. Eur. J. Biochem. 1974, 47, 469-474. [CrossRef]

113. Victorino, V.; Panis, C.; Campos, F.; Cayres, R.; Colado-Simão, A.; Oliveira, S.; Herrera, A.; Cecchini, A.; Cecchini, R.J.A. Decreased oxidant profile and increased antioxidant capacity in naturally postmenopausal women. Age 2013, 35, 1411-1421. [CrossRef]

114. Lowry, O.H.; Rosebrough, N.J.; Farr, A.L.; Randall, R.J. Protein measurement with the folin phenol reagent. J. Biol. Chem. 1951, 193, 265-275. [PubMed]

115. Miller, G.L. Protein determination for large numbers of samples. Anal. Chem. 1959, 31, 964. [CrossRef]

(C) 2020 by the authors. Licensee MDPI, Basel, Switzerland. This article is an open access article distributed under the terms and conditions of the Creative Commons Attribution (CC BY) license (http://creativecommons.org/licenses/by/4.0/). 